\title{
The frailty phenotype in hemodialysis patients and its association with biochemical markers of mineral bone disorder, inflammation and nutrition
}

\author{
ALMA MUTEVELIĆ-TURKOVIĆ ${ }^{*}$, HALIMA RESIĆ ${ }^{1}$, BADEMA ČENGIĆ ROLJIĆ1, \\ AMELA DERVIŠEVIĆ ${ }^{2}$, AMELA BEĆIRAGIĆ ${ }^{1}$
}

\author{
${ }^{1}$ Clinic for Hemodialysis, Clinical Centre University of Sarajevo, 71000 Sarajevo, Bosnia and Herzegovina \\ ${ }^{2}$ Department of Human Physiology, Faculty of Medicine, University of Sarajevo, 71000 Sarajevo, Bosnia and Herzegovina
}

\begin{abstract}
Introduction: Frailty is a state of increased vulnerability to physical stressors. It is common in patients with end-stage renal disease (ESRD) who are on hemodialysis (HD).

The aim of this study was to analyze the presence of frailty phenotype among HD patients and to evaluate their interrelationship with different biochemical markers.

Methods: For the frailty assessment the Frailty Phenotype by Fried et al. was used, where frailty was reported if three of the following criteria were met: unintentional weight loss, self-reported exhaustion, weakness, slow walking speed and low physical activity. From 281 HD patients, 126 patients were frail, 58 were pre-frail (two criteria were met) and the rest of the study population were robust (97 patients). BMI was calculated for all patients and venous blood samples were taken to determine laboratory parameters for bone alkaline phosphatase (BAP), phosphate (P), potassium (K), C-reactive protein (CRP) and albumin.

Results: Patients who were on HD longer than 60 months have more characters of frailty $(\mathrm{p}=0.019)$. A statistically significant positive correlations between frailty score and BAP (rho $=0.189$; $\mathrm{p}=0.001$ ), and CRP (rho $=0.233 ; \mathrm{p}<0.001)$ were observed, and significant negative correlations between frailty score and albumin (rho $=-0.218 ; \mathrm{p}<0.001)$ and $\mathrm{K}(\mathrm{rho}=-0.198 ; \mathrm{p}=0.001)$.

Conclusions: The associations of frailty with markers of mineral bone disorder, inflammation and nutrition indicate the importance of these parameters in the indirect assessment of the frailty phenotype in HD patients.
\end{abstract}

Key words: frailty, hemodialysis, mineral bone disorder, inflammation, nutrition.

\section{INTRODUCTION}

Frailty is a state of increased vulnerability to physical stressors. It is a result of progressive and sustained degeneration in multiple physiological systems, which is common in those with chronic kidney disease (CKD) [1]. Frailty is especially present in end stage renal disease (ESRD) patients who are on some type of renal replacement therapy as some studies have reported a frailty prevalence of $>60 \%$ in dialysis-dependent CKD patients [2]. Cross-sectional studies suggest that the prevalence of frailty increases as kidney disease progresses [3]. Although chronic disease and aging contribute to frailty, there may also be potentially reversible contributors, such as acute illnesses, inflammation, and poor nutritional status, and frailty may not always be a permanent or progressive condition [3].

Recently, there have been efforts to create a definition of frailty to aid in its diagnosis and to categorize its severity. Two principal concepts are described: The Fried Phenotype Model of Frailty, which focuses on physical frailty, and the more holistic Cumulative Deficit Model of Frailty, also known as the Frailty Index, which considers a broad range of medical and psychological conditions and considers functional impairment [4].

Fried et al. [5] described the Frailty Phenotype (FP) as a clinical syndrome involving at least three of the following: unintentional weight loss, self-reported exhaustion, weakness, slow walking speed and low physical activity. They demonstrated that their definition of physical frailty, although having some overlap with disability and comorbidity, was a distinctive syndrome and independently predictive of adverse outcomes, including falls, hospitalization and death [5].

The aim of this study was to determine the prevalence of the FP among hemodialysis patients (HD) and to evaluate their relationship between biochemical markers of mineral bone disease, inflammation and nutritional status. 


\section{MATERIALS AND METHODS}

\section{Study population}

This cross-sectional study involved 281 (112 female, 169 male) ESRD patients older than 18 years, undergoing maintenance HD treatment for more than 3 months at the Clinic of Hemodialysis at the University Clinical Center Sarajevo. The mean age of the study participants was $54.2 \pm 11.91$ years, with a mean duration of HD treatment $60.5 \pm 39.21$ months.

Enrollment criteria included: being over the age of 18 and undergoing HD for at least three months. Exclusion criteria were age younger than 18 years old, acute renal failure, pre-dialysis patients with other stages of chronic renal disease and chronic renal failure with temporary dialysis (less than 3 months), as well as patients undergoing radiotherapeutic and chemotherapeutic treatment.

\section{Demographic data and clinical parameters}

The method of collecting data is performed through patients' electronic medical records, where we monitored demographic and clinical data of patients (gender, age, duration of the HD tretament expressed in months, type of vascular acces).

For the frailty assessment the Frailty Phenotype by Fried et al. [5] as the self-reported questionnaire was used. Frailty was reported if three of the five mentioned criteria above were met (unintentional weight loss, self-reported exhaustion, weakness, slow walking speed and low physical activity), pre-frailty if two criteria were met and non-frail or robust if there was just one or none criteria. Those data were obtainted from the anamnessis, physical examination and the medical history of the patient. In our study group $97(34.5 \%)$ were robust, 58 (20.6\%) were pre-frail, while 126 (44.8\%) patients had the characteristic of the frailty phenotype.

\section{Laboratory analysis}

Venous blood samples were drawn from each patient before the HD treatment after an 8-hr to 12 -h overnight fast in the midldle of the week and before the second HD treatment in that week at the Clinic for hemodialysis. All blood samples were send to the central laboratory of the Clinic for chemistry and biochemistry in the Clinical Center University of Sarajevo.
As biochemical markers of mineral bone disorder (MBD) the serum concentrations of calcium $(\mathrm{Ca})$, phosphate $(\mathrm{P})$, intact parathyroid hormone (iPTH), and bone alkaline phosphatase (BAP) were used.

Minerals were measured by the ion-selective electrode diluted (indirect) method, the reference values for $\mathrm{Ca}$ are from 2.14 to $2.75 \mathrm{mmol} / \mathrm{l}$ and for $\mathrm{P}$ are from $0.81-1.58 \mathrm{mmol} / \mathrm{l}$. PTH was measured by an immunometric immunoassay technique with reference values from 14 to $86 \mathrm{pg} / \mathrm{ml}$.

To asses nutritional status the serum values of albumin and potassium $(\mathrm{K})$ were assesed as well as the BMI were measured and calculated. The albumin concentration was determined by the spectrophotometricall method using bromine cresol green reagent (referent range from 35 to $50 \mathrm{~g} / \mathrm{l}$ ). Potassium as well as other minerals were measured by the ion selective electrode diluted (indirect) method with reference values from 3.9-5.1 mmol/l. Body mass index (BMI) was calculated as weight $(\mathrm{kg})$ divided by height squared $\left(\mathrm{m}^{2}\right)$. According to the World Health Organization (WHO) criteria, BMI values in the range $18-25 \mathrm{~kg} / \mathrm{m}^{2}$ were considered as normal weight, $26-29 \mathrm{~kg} / \mathrm{m}^{2}$ as overweight, and BMI equal to or greater than $30 \mathrm{~kg} / \mathrm{m}^{2}$ as obese [6].

The main inflammation marker C-reactive protein (CRP) was used in order to evaluate the inflammation status in our study group. CRP was measured by the turbidimetric/immunoturbidimetric method (referent range from $0-5 \mathrm{mg} / \mathrm{L}$ ).

Upon careful explanation of the study procedure, an informed consent in writing was obtained from all patients. The study was approved by the UCCS Ethics Committee. Investigations were carried out in accordance with the Declaration of Helsinki as revised in 2000.

\section{Statistical analysis}

The normality and variance homogeneity of data for continuous variables were tested using the Kolmogorov-Smirnov test. Categorical variables were expressed as numbers (n) and percentages (\%) and differences between them were assessed using Chi-square test. Results of descriptive statistics for continuous variables are presented as mean values \pm standard deviation (SD). The difference between the continuous variables was assessed by the Student's t-test.

Spearman's correlation coefficient was used to express the association between variables. 
Statistical significance of the obtained results was set at $\mathrm{p}<0.05$. All statistical analyses were conducted using Statistical Package for the Social Sciences (SPSS) version 13.0 for Windows (Chicago, IL, USA).

\section{RESULTS}

The demographic data and clinical characteristics of the study population are presented in Table 1.

Male patients were more represented in the study group (60.1\%) as well as in the frail (56.3\%), and pre-frail (62.1\%) group of patients. No statistically significant association was determined between gender and the frailty phenotype.

Most patients included in our study (48.4\%) were in the age group from 41 to 65 years. $53.2 \%$ patients with the frailty phenotype were older than 65 years, while $39.7 \%$ of them were aged from 41 to 65 years. In the pre-frail and robust groups of patients, most of them were younger than 65 years. A statistically significant association between age and the frailty phenotype was noticed ( $\mathrm{p}=0.009)$.

$46 \%$ frail patients were on HD treatment longer than 60 months, whereas the pre-frail and robust patients were on $\mathrm{HD}$ treatment between 13 and 60 months. A statistically significant association between HD duration and the frailty phenotype was noticed $(\mathrm{p}=0.019)$.

Most of the patients in the frail, pre-frail and robust had arteriovenous fistula. A statistically significant association $(\mathrm{p}=0.009)$ between the use of AVF compared to other vascular accesses was noticed in all three HD patients groups.

The correlation between frailty score and serum markers of mineral bone disorder are presented in Table 2. There was no significantly association between the frailty score and biochemical markers of mineral bone disorder, $\mathrm{Ca}, \mathrm{P}$ and $\mathrm{iPTH}$. Despite that, frailty score showed a statistically significant positive correlation with $\operatorname{BAP}($ rho $=0.189 ; \mathrm{p}=0.001$ ).

Table 3 shows correlations between frailty sum score and serum markers of inflammation and nutrition status. There was a statistically significant positive association between frailty score and CRP (rho $=0.233 ; \mathrm{p}<0.001)$. Statistically significant negative associations were observed between frailty sum score and serum markers of nutrition status: serum albumin (rho $=-0.218 ; \mathrm{p}<0.001)$ and $\mathrm{K}(\mathrm{rho}=-0.198 ; \mathrm{p}=0.001)$.

Table 1

Demographic data and clinical parameters of the study population

\begin{tabular}{|c|c|c|c|c|c|c|}
\hline & & $\begin{array}{c}\text { All } \\
\mathrm{n}=281\end{array}$ & $\begin{array}{c}\text { Non-frail } \\
\mathrm{n}=97\end{array}$ & $\begin{array}{c}\text { Pre-frail } \\
\mathrm{n}=58\end{array}$ & $\begin{array}{c}\text { Frail } \\
\mathrm{n}=126\end{array}$ & $\mathrm{p}$ value \\
\hline \multicolumn{2}{|c|}{ Gender (Male) } & $169(60.1 \%)$ & $62(63.9 \%)$ & $36(62.1 \%)$ & $71(56.3 \%)$ & 0.491 \\
\hline \multirow{3}{*}{$\begin{array}{c}\text { Age } \\
\text { groups } \\
\text { (yrs.) }\end{array}$} & $\leq 40$ & $26(9.3 \%)$ & $12(12.4 \%)$ & $5(8.6 \%)$ & $9(7.1 \%)$ & \multirow{3}{*}{0.009} \\
\hline & $41-65$ & $136(48.4 \%)$ & $57(58.8 \%)$ & $29(50.0 \%)$ & $50(39.7 \%)$ & \\
\hline & $>65$ & $119(42.3 \%)$ & $28(28.9 \%)$ & $24(41.4 \%)$ & $67(53.2 \%)$ & \\
\hline \multirow{3}{*}{$\begin{array}{c}\text { HD } \\
\text { duration } \\
\text { (months) }\end{array}$} & $\leq 12$ & $61(21.7 \%)$ & $18(18.6 \%)$ & $18(31.0 \%)$ & $25(19.8 \%)$ & \multirow{3}{*}{0.019} \\
\hline & $13-60$ & $115(40.9 \%)$ & $50(51.5 \%)$ & $22(37.9 \%)$ & $43(34.1 \%)$ & \\
\hline & $>60$ & $105(37.4 \%)$ & $29(29.9 \%)$ & $18(31.0 \%)$ & $58(46.0 \%)$ & \\
\hline \multirow{3}{*}{$\begin{array}{c}\text { Type of } \\
\text { vascular } \\
\text { access }\end{array}$} & $\begin{array}{c}\text { Temporary } \\
\text { CVC }\end{array}$ & $19(6.8 \%)$ & $6(6.2 \%)$ & $1(1.7 \%)$ & $12(9.5 \%)$ & \multirow{3}{*}{0.009} \\
\hline & $\begin{array}{c}\text { Permanent } \\
\text { CVC }\end{array}$ & $56(19.9 \%)$ & $10(10.3 \%)$ & $13(22.4 \%)$ & $33(26.2 \%)$ & \\
\hline & AV fistula & $206(73.3 \%)$ & $81(83.5 \%)$ & $44(75.9 \%)$ & $81(64.3 \%)$ & \\
\hline
\end{tabular}

Data are presented as number of cases (n) and percentages (\%); $\mathrm{p}$ - probability; HD - hemodialysis; CVC - central venous catheter; AV - arteriovenous

Table 2

Correlation between frailty sum score and serum markers of mineral bone disorder

\begin{tabular}{|l|c|c|}
\hline \multirow{2}{*}{ Parameters } & rho & Frailty sum score \\
\cline { 2 - 3 } & -0.062 & 0.304 \\
\hline $\mathrm{Ca}(\mathrm{mmol} / \mathrm{l})$ & -0.049 & 0.414 \\
\hline $\mathrm{P}(\mathrm{mmol} / \mathrm{ll})$ & 0.022 & 0.717 \\
\hline $\mathrm{iPTH}(\mathrm{pg} / \mathrm{mL})$ & 0.189 & 0.001 \\
\hline $\mathrm{BAP}(\mathrm{U} / \mathrm{L})$ & & \\
\hline
\end{tabular}

Ca - total calcium; P - phosphate; iPTH - intact PTH; BAP - bone alkaline phosphatase; rho - Spearman's correlation coefficient 
Table 3

Correlation between frailty sum score and serum markers of inflammation and nutrition status

\begin{tabular}{|c|c|c|}
\hline \multirow{2}{*}{ Parameters } & rho & Frailty sum score \\
\cline { 2 - 3 } & 0.233 & $<$-value \\
\hline CRP $(\mathrm{mg} / \mathrm{L})$ & -0.218 & $<0.001$ \\
\hline Albumins $(\mathrm{g} / \mathrm{l})$ & -0.198 & 0.001 \\
\hline $\mathrm{K}^{+}(\mathrm{mmol} / \mathrm{l})$ & -0.083 & 0.168 \\
\hline BMI $(\mathrm{kg} / \mathrm{m} 2)$ & &
\end{tabular}

CRP - C- reactive protein; K - potassium; BMI - Body mass index; rho - Spearman's correlation coefficient

\section{DISCUSSION}

To the best of our knowledge, this study is the first research which assessed the frailty phenotype using the assessment tool by Fried in HD patients in Bosnia and Herzegovina.

The demographic structure of our patients showed $44.8 \%$ frail phenotype prevalence, which is very similar to the report of Musso et al. [7]. In their review this authors reported a prevalence of $42 \%$ frailty among HD patients and these have a higher risk of mortality and a higher number of hospitalization episodes. Also, in the systematic review of Chowdhury et al. [8] it was reported that frailty is prevalent in patients with CKD and it is associated with an increased risk of adverse health outcomes.

In our study group $53.2 \%$ frail patients were older than 65 years, while $39.7 \%$ of them were aged from 41 to 65 years. The demographic structure of the study conducted in Japan at six institutions by Takeuchi et al. [9] were similar to our study in terms of age, where they described that the prevalence of frailty increased steadily with age.

This study also states that the female gender is independently associated with frailty which is different from our findings where more frail patients were men. This difference can be explained by different demographic characteristic whereas our study included a larger number of male patients.

Our study showed that patients who are longer on a HD treatment have more frail phenotype characteristics. These findings are similar to those of a study of Garcia-Canton et al. where patients who spent longer time on HD were more frail [10] and this can be explained by the fact that CKD is more frequent in older patients and it also favors earlier onset of frailty compared with patients of similar age, without CKD.

In the frail, pre-frail and robust $\mathrm{HD}$ patient group the most common vascular access used was arteriovenous fistula (AVF) with a statistically significant association between the uses of this vascular access compared to others in all three HD patients groups. This finding is expected because our Center follows the current international guidelines which encourage the creation of AVF as a first choice for dialyses access and as a last resort insertion of central venous catheter [11].

Our study showed that the type of vascular access-primary AVF may favor more frailty in patients. Despite the multiple studies concentrating on age and vascular access, there has been negligible work on the association of frailty and vascular access. Limited data exist on this relationship, but it appears that frailty may have an association with poorer outcomes from vascular access [12]. Johansen et al. [2] assessed frailty in >3000 incident dialysis patients and determined that individuals with a permanent vascular access (like AVF) were less likely to be frail with hazard ratio $0.72(95 \% \mathrm{CI}$ 0.51-0.98) and this was independent of the time of nephrology referral. Those findings are different from our result and they can be explained by the fact that the prevalence of more senior individuals receiving $\mathrm{HD}$ has increased in recent years. In addition, current international guidelines advocate AV creation as first choice for vascular access in HD patients. Not just that these factors play a big role but also AVF per se can have impact on the cardiac function which can lead to its weakness and thus accelerate the persistent disease and therefore the frailty phenotype as well [13]. Due to complexity in decision making in dialysis access, frailty assessment could be a key element in providing patient-centered approach in planning and maintaining vascular access for dialysis [12].

Our study showed that biochemical markers of mineral bone disorder like $\mathrm{Ca}$, iPTH and as well as $\mathrm{P}$ did not correlate significantly with the frailty phenotype. However, BAP showed a statistically significant positive association with frailty score. The observational prospective longitudinal study by Garcia-Canton et al. [10], which included 277 prevalent HD patients and was demographically very similar to ours, stated that the association 
between frailty and laboratory parameters of bone and mineral metabolism is unclear.

Another cross-sectional study by Yoneki et al. [14], which included 214 (90 women, 124 men) Japanese outpatients undergoing maintenance HD and defined Frailty based on criteria set forth by the Cardiovascular Health Study, aimed to assess the association between frailty and bone loss in patients undergoing $\mathrm{HD}$ and showed that parameters like $\mathrm{Ca}$, $\mathrm{P}$ and $\mathrm{iPTH}$ decreased significantly with increasing levels of frailty in both sexes. These differences in the association of laboratory findings for mineral bone disorder and frailty in HD patients found in previous studies may be due to several reasons, such as differences in the study populations in terms of commorbidities, and inclusion of prevalent or incident patients. However, they may also be due to differences in the methods used to detect frailty. Also, CKD itself, which further on goes into ESRD causing vitamin $\mathrm{D}$ deficiency leads to a mineral imbalance causing secondary hyperparathyroidism, whose consequence is renal osteodystrophy [15]. The bone loss is a complication of ESRD which is further on deteriorated by HD itself. Besides, frailty should be also considered a risk factor for bone loss in patients undergoing HD [14].

When it comes to biochemical markers of nutrition, results of the present study demonstrated statistically significant negative associations between frailty sum score and serum markers of nutrition status: serum albumins and $\mathrm{K}$. Our results are in accordance with the results of similar studies that stated association between frailty and lower serum values of albumin $[10,3]$.

Our results show a significant positive association between frailty score and CRP. Due to the nature of ESRD and the renal replacement therapy in the form of HD, our patients are in a chronic inflammatory state. Considering that most of them are frail, it is to be expected that the results of our study showed a positive association between CRP as a marker of inflammation and the frailty phenotype. Our findings are inconsistent with some other studies of frailty in HD patients which failed to find an association of frailty with the inflammation marker CRP [10]. A possible reason for this discrepancy in the results may be related to the differences in the study design and sample size or differences in the study populations in terms of age and commorbidity and the assessment parameter for frailty. On the other hand similar results with ours were observed in a study by López-Montes et al. [16], where authors found not only an association with the severity of frailty phenotype with higher CRP levels, but also an improvement of this parameter by patients who survived their 12-month follow up period compared to the non frail ones.

Hendra et al. in their study assessed HD patients with the mortality rate after testing positive for the novel SARS-CoV-2 by RT-PCR and identified prognostic risk factors associated with poor outcome including age, frailty and markers of inflammation [17].

Frailty is most present in older people where in addition CKD accelerates the aging process. These combined effects of chronological and pathological aging may explain why the frailty phenotype is much more common in this population. Also, many years on dialysis lead to the development of chronic complications which lead to the expression of the frailty phenotype. It is very important that the risk factors for frailty are recognized on time in hemodialysis patients so a lot of measures can be taken to prevent frailty and also improve the proper treatment approach in the management of frailty.

However, there were several limitations in this study. Primarily, the study was conducted as a cross-sectional study, so it was not possible to completely eliminate the bias in the patient selection. Also, the study included a relatively small sample of patients from one research center (a single center study). Because of the limitations mentioned above a multi-center prospective study with a large-scale sample is needed in order to confirm the accuracy of the results.

\section{CONCLUSION}

The results of our study showed that frailty is more present in male and in older HD patients. Patients who are longer on HD treatment have a higher value of the frailty score, and are therefore more frail.

The positive association of the frailty phenotype with BAP as a marker of mineral bone disease and with CRP as a marker of inflammation, and a negative association with albumin and potassium as a marker of nutrition can indicate the importance of these markers in the indirect assessment of the frailty phenotype and their management in HD patients.

Extensive and well controlled prospective studies are needed in order to supplement and clarify as well as confirm these results. 
Introducere. Fragilitatea reprezintă o stare de vulnerabilitate crescută în fața stresorilor fizici. Este comună la pacienții cu ESRD și hemodializă (HD). Scopul studiului a fost de a evalua fenotiopul de fragilitate la pacienți cu $H D$.

Metode. Pentru evaluarea fragilității a fost folosită evaluarea descrisă de Fried et al. în care fragilitatea a fost definită după măcar unul din criteriile următoare: scădere ponderală involuntară, epuizare, slăbiciune și activitate fizică scăzută. Din 281 de pacienți cu HD, 126 aveau fragilitate, 58 aveau pre-fragilitate și 97 erau robuști. Pacienților le-au fost determinate BMI și fosfatază alcalină (BAP), fosfor, potasiu, proteină C reactivă și albumină.

Rezultate. Pacienții sub dializă mai lungă de 60 luni aveau caracteristici ale fenotipului fragil $(p=0,019)$. S-a observat o asociere semnificativă între scorul de fragilitate şi BAP $(r=0,189, p=0,001)$ și CRP $(r=0.233, p=0,001)$. S-au observat asocieri negative intre scorul de fragilitate și albumină sau $K$.

Concluzii: Asocierea fragilității cu markerii minerali osoși, inflamație și nutriție indică importanța parametrilor în evaluarea fenotipului fragil la pacienții cu $H D$.

Correspondence to: Alma Mutevelić-Turković, MD, Clinic for Hemodialysis, Clinical Centre University of Sarajevo Bolnička 25, 1000 Sarajevo, Bosnia and Herzegovina

Telephone number: 0038762270725

E-mail: amutevelic@yahoo.com

Conflict of interest disclosure: The authors declare no conflict of interest.

Acknowledgements: None.

\section{REFERENCES}

1. NIXON AC., BAMPOURAS TM., PENDLETON N., WOYWODT A., MITRA S., DHAYGUDE A. Frailty and chronic kidney disease: current evidence and continuing uncertainties. Clin Kidney J. 2018; 11(2): 236-245.

2. JOHANSEN KL., CHERTOW GM., JIN C., KUTNER NG. Significance of frailty among dialysis patients. J Am Soc Nephrol 2007; 18: 2960-2967.

3. JOHANSEN KL., DALRYMPLE LS., DELGADO C., CHERTOW GM., SEGAL MR., CHIANG J., et al. Factors Associated with Frailty and Its Trajectory among Patients on Hemodialysis. Clin J Am Soc Nephrol. 2017; 12(7): 1100-1108.

4. WALSTON JD., BANDEEN-ROCHE K. Frailty: a tale of two concepts. BMC Med 2015; 13: 185.

5. FRIED LP., TANGEN CM., WALSTON J., NEWMAN AB., HIRSCH C., GOTTDIENER J., et al. Frailty in older adults: evidence for a phenotype. J Gerontol A Biol Sci Med Sci 2001; 56(3): 146-56.

6. WORLD HEALTH ORGANIZATION. Obesity: preventing and managing the global epidemic. Geneva: WHO; 1997.

7. MUSSO CG., JAUREGUI JR., NÚÑ̃Z JFM. Frailty phenotype and chronic kidney disease: a review of the literature. Int Urol Nephrol. 2015;47(11):1801-7.

8. CHOWDHURY R., PEEL NM., KROSCH M., HUBBARD RE. Frailty and chronic kidney disease: A systematic review. Arch Gerontol Geriatr. 2017;68:135-142.

9. TAKEUCHI H., UCHIDA HA., KAKIO Y, OKUYAMA Y., OKUYAMA M., UMEBAYASHI R., et al. The Prevalence of Frailty and its Associated Factors in Japanese Hemodialysis Patients. Aging Dis. 2018; 9(2):192-207.

10. GARCIA-CANTON C., RODENAS A., LOPEZ-APERADOR C., RIVERO Y., ANTON G., MONZON T., et al. Frailty in hemodialysis and prediction of poor short-term outcome: mortality, hospitalization and visits to hospital emergency services. Ren Fail. 2019; 41(1): 567-575.

11. KDOQI. KDOQI clinical practice guideline for vascular access: 2019. [Cited 06 May 2021]. Available from: https://www.ajkd.org/article/S0272-6386(19)31137-0/fulltext

12. KUNINGAS K, INSTON N. Age is just a number: Is frailty being ignored in vascular access planning for dialysis? J Vasc Access. 2021; 11(2):972-982.

13. RAO N, DUNDON BK, WORTHLEY IM, FAULL JR. The Impact of Arteriovenous Fistulae for Hemodialysis on the Cardiovascular System. Semin Dial 2016; 29(3):214-21.

14. YONEKI K., KITAGAWA J., HOSHI K., HARADA M., WATANABE T. , SHIMODA T , et al. Association between frailty and bone loss in patients undergoing maintenance hemodialysis. Bone Miner Metab. 2019 Jan;37(1):81-89.

15. SNEŽANA UNČANIN-MEĐOVIĆ. Hronična bubrežna bolest. In: Senija Rašić. Klinička Nefrologija.Sarajevo: Medicinski fakultet Univerziteta u Sarajevu. 2020; 348-349.

16. LOPEZ-MONTES A, MARTINEZ-VILLAESCUSA M, PEREZ-RODRIGUEZ A, ANDRES-MONPEAN E, MARTINEZDIAZ M, MASIA J, GIMENEZ-BACHS JM,et al. Frailty, physical function and affective status in elderly patients on hemodialysis. Arch Gerontol Geriatr. 2020; 87(1):39-76. 
17. HENDRA H, VAJGEL G, ANTONELOU M, NERADOVA A, MANSON B, CLARK SG,et al. Identifying prognostic risk factors for poor outcome following COVID-19 disease among in-centre haemodialysis patients: role of inflammation and frailty. J Nephrol. 2021; 9(2):1-9.

Received $19^{\text {th }}$ May 2021 